\title{
Facies association and depositional environment of fan-delta sequence in southwest Kathmandu Basin, Nepal
}

\author{
*Naresh Kazi Tamrakar'1, Pramila Shrestha ${ }^{2}$ and Surendra Maharjan ${ }^{3}$ \\ ${ }^{1}$ Central Department of Geology, Tribhuvan University, Kathmandu, Nepal \\ ${ }^{2}$ Department of Irrigation, Ministry of Irrigation, Jawalakhel, Lalitpur, Nepal \\ ${ }^{3}$ East Management and Engineering Services, Pvt. Ltd., Lalitpur, Nepal
}

\begin{abstract}
Lake marginal sedimentation prevailed around the Paleo-Kathmandu Lake. Owing to the difference in local basin conditions; tectonics, source rock types and river systems therein, the lake marginal environments and sedimentary facies associations differ around the Paleo-Kathmandu Lake. In this study, the basin-fill sediments of southwestern margin of the Kathmandu Basin were studied for the sediments recorded in vertical sequences at various localities and facies analysis was made. Mainly eight facies were recognised. They were matrix-supported massive gravel (Gmm), matrix-supported graded gravel (Gmg), gravelly fine or mud (GF), massive silt (Fsm), massive mud (Fm), ripple-laminated silt or laminated silt/mud/clay (Fl), carbonaceous clay (C), and incipient soil with roots (Fr). Four facies associations that were identified were proximal fan-delta facies association (FA1), mid fan-delta facies associaiton (FA2), distal fan-delta facies association (FA3), and gravelly sinuous river facies association (FA4). Remarkably, these facies associations do not contain any sandy facies and foreset bedding of Gilbert-type. The fan-delta region was characterised by flood-dominated flows and vertical accretion of fines in the flood basins, and vegetated swamps rich in organic sediments. The distribution of facies associations suggests extensive lake transgression followed by rapid lake regression. The recent river system then incised the valley against local upliftment due to faulting or lowering of base level of the main river in the Kathmandu Basin probably related to draining out of the lake water.
\end{abstract}

\section{INTRODUCTION}

Marginal sedimentation prevailed around the Paleo-Kathmandu Lake before 30,000 years (Saijo and Kimura 2007). The lithofacies, however, differed from region to region at the basin margins of the lake. For example, the fluvio-deltaic sequence of $\mathrm{NE}$ region was mainly deposited in delta front and as sandy foresets of aggrading delta (Sakai et al. 2001). The sediments of the northwest region also indicate sandy deltaic foresets. The sediments of the southern margin of the Paleo-Kathmandu Lake were deposited from allvial fan (Paudel and Sakai 2008). Existence of pedimont debris overlying organic rich mud were reported from the northwestern and southwestern

*Corresponding author:

E-mail address: ntamrakar@hotmail.com margins of the Kathmandu Basin (Saijo and Kimura 2007). Sakai et al. (2001) reported marginal to open lacustrine facies called Kalimati Formation, which is composed of the Basal Lignite Member and the upper carbonaceous clay with diatomaceous laminite. The sediments in the southwestern margin (present study area), however, consist of gravel, gravelly mud, mud and silt, and lack sand and foreset sand beds. Sediments there could have been deposited somewhat in different setup, and could have been controlled by faults and the nature of the source rocks in the basin. The overall setting could be a fan-delta system.

McPherson et al. (1987) redefined fan-delta as an alluvial fan that is deposited directly into a standing body of water. Fan-deltas are deposited immediately adjacent to highland region, usually a fault-bounded margin, and occupy a relatively a narrow space between highland and a standing body of water. Even 


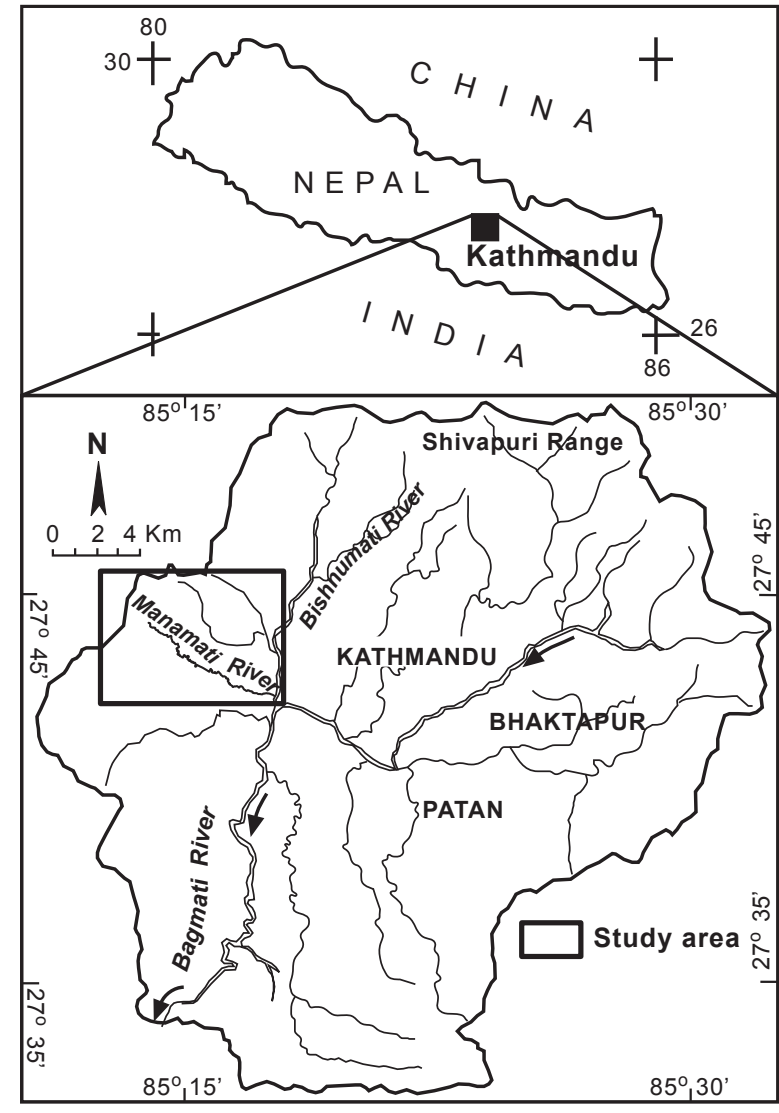

Fig. 1 Location of study area

fan-delta system of non-Gilbert-type can be a possible environment for fan debauching into a shallow and small lake with fluctuation of water depth (Billi et al. 1990). The present paper intends to document the sedimentary record, and provide measured lithofacies section, description and environmental interpretation.

\section{GEOLOGICAL SETTING}

The study area locates in the Central Nepal Lesser Himalayas in the southwest of Kathmandu basin (Fig. 1), which was a former marginal lake. The Paleo-Kathmandu Lake existed between 2.8 million years to about $10 \mathrm{kyr}$ B.P., and drained out from the southern region of the basin and disappeared in around 10 kyr B.P. (Sakai 2001). The Manamati River area, which lies in the southwest of the Kathmandu Basin, offers good sedimentary records exposed on the terrace scarps and river valleys. The river valley is surrounded by NW-SE ridges; ThapleVirkot-Kallabari, located in the north, and Indrasthan-
Godamthok-Buldol in the south (Fig. 2). The river valley opens and widens southeastwards. The Lupan Khola, which contributes the Manamati River from the north, produces another prominent valley. The latter dissects the uplifted bedrocks, which extend E$\mathrm{W}$ and dip towards north, in the central portion of the Manamati River basin.

The southern ridges (Indrasthan-GodamthokBuldol) are composed of sandstone, siltstone, calcareous siltstone and shale of the Tistung Formation (Fig. 2). The central ridge is produced by the rocks of the Sopyang Formation composed mainly of calcareous shale, slate and phyllite. The ridge is discontinuous and forms portion of the northern limb of the Bhimdhunga anticline displaced by two steep faults (Fig. 3). This ridge distinctly separates northern valley of the Lupan Khola with the southern of the Manamati River (Fig. 4).

The summit and the north-facing slopes of the northern ridges are formed by limestone, siliceous limestone, argillaceous limestone and calcareous siltstone of the Chandragiri Formation, which dip northwards. The south-facing slopes of the northern ridges are composed of the rocks of the Tistung Formation. The strata of the northern ridges form the north limb of the Bhimdhunga Anticline. There exists fault between the Tistung and the Chandragiri Formations (Fig. 3).

The basin-fill sediments distribute to the width of $2 \mathrm{~km}$ and extend laterally NW-SE along the major valleys of the Manamati River and the Lupan Khola. The Lupan Khola forms a hanging valley and incises the E-W extending central ridge. The boundary of the fan-delta sediment exceeds the elevation of 1400 $\mathrm{m}$ in the northwest region. The sediment also overlies most of the central ridge in this region and some bedrocks in the southwestern portion with an angular unconformity. At the southern and northwestern margins, the basin-fill sediments have been partly overlain by recent alluvial fans. However, in the northern margin they are transitional to the residual soil of the rock formations.

The map published by DMG (1998) assigned the area into the Lukundol Formation. According to Sakai (2001), the Lukundol Formation is composed of organic rich dark mud, silt-sand rhythmite, coarse sand, granule and massive pebbly mud. Paudel and 


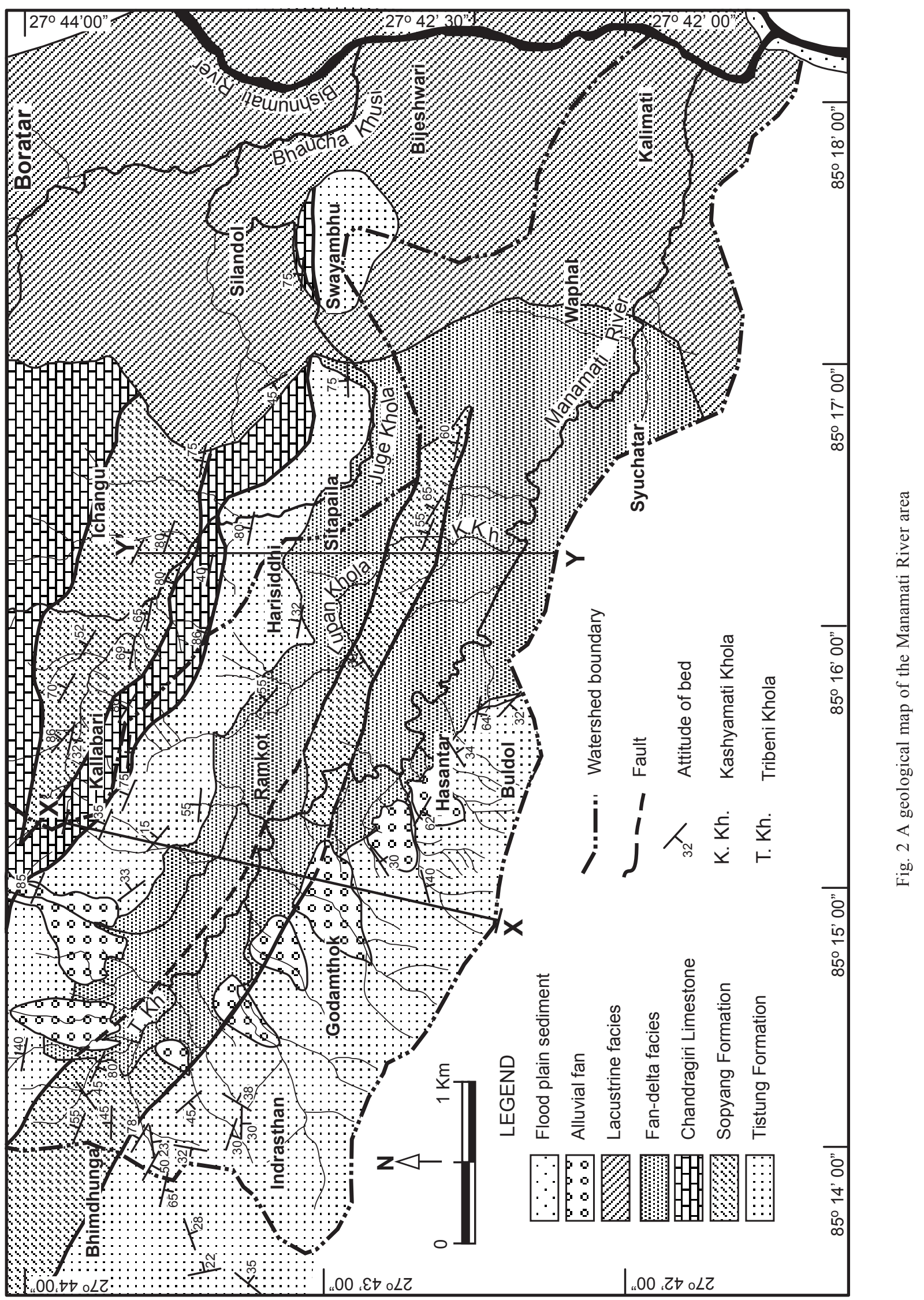




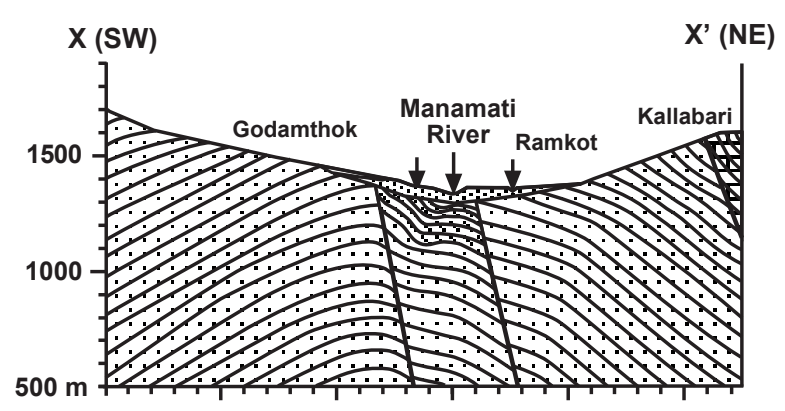

(a)

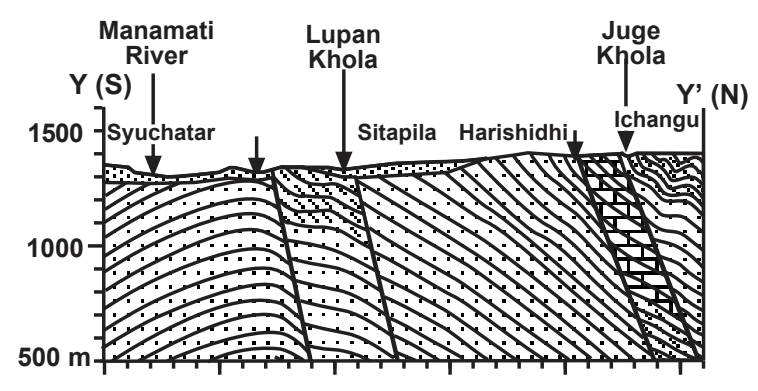

(b)

Fig. 3 Geological cross-sections along $X-X^{\prime}$ and $Y-Y^{\prime}$ shown in Fig. 2
Sakai (2008) distinguished three parts of the Lukundol Formation in the southern margin of the Kathmandu Basin. These are: (a) basal part comprising crossbedded, coarse pebbly micaceous sand, bioturbated silty sand, silt, and carbonaceous clay, (b) middle part with silty and fine sand, cross-laminated/ripple laminated coarse sand, carbonaceous mud and lignite, and (c) upper part with fine laminated silty sand, fine sand, carbonaceous mud, lignite, and diatomaceous bed. The basin-fill sediments of the Manamati River area do not resemble completely with the lithofacies of the southern Kathmandu Basin. The remarkable here is the lack of sandy sediments and the presence of matrix-supported massive gravel that indicates viscous and high strength debris flow events. Therefore, the sedimentary facies associations distributed in the southwest part of the Kathmandu Basin do not fully fit with that of the Lukundol Formation.

The Manamati River has evolved as a longitudinal river system. To this river, north- and south-sloping,

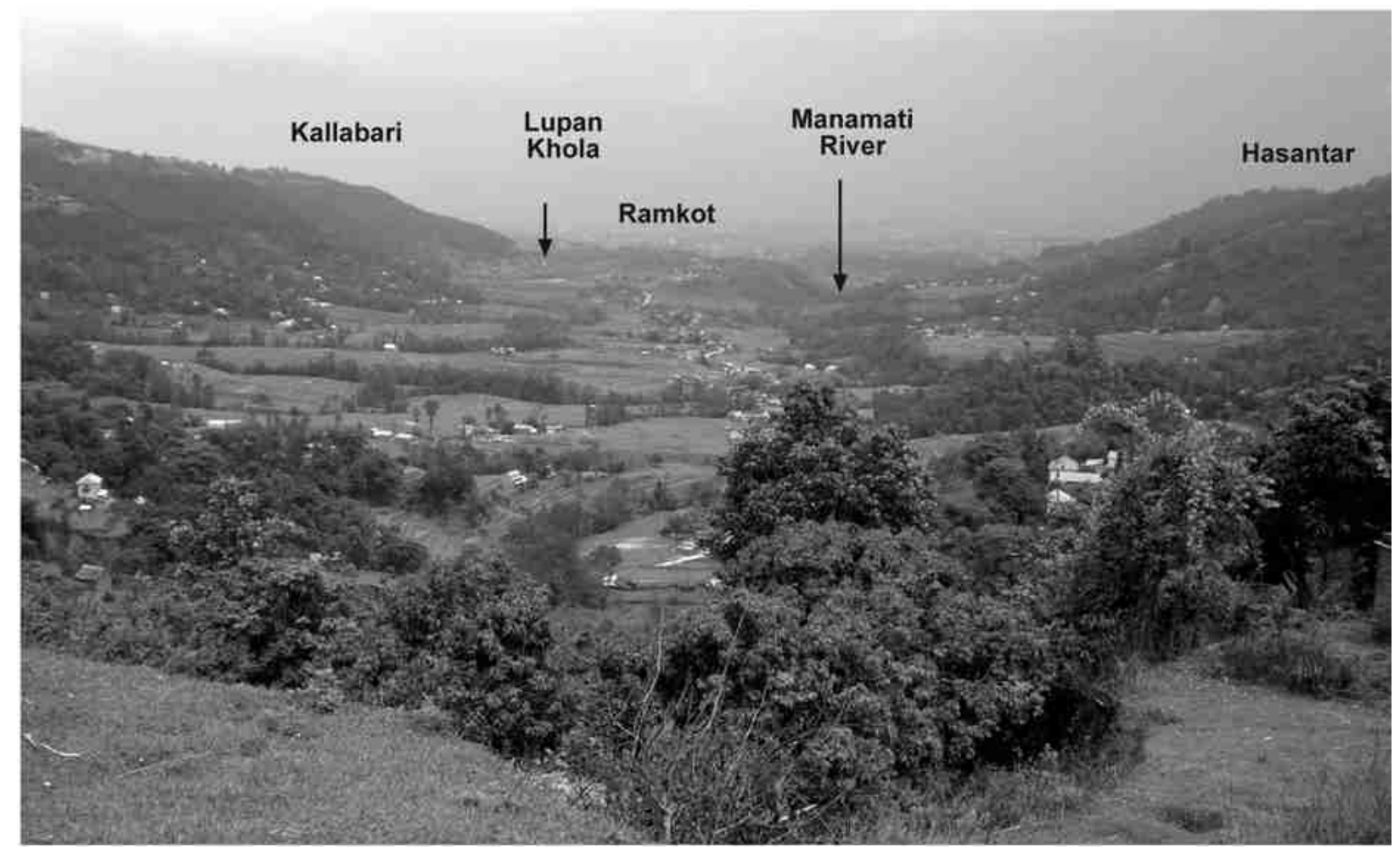

Fig. 4 A photograph showing southeast view of the Manamati River area from Bhimdhunga indicating northern and southern ridges, and valleys of the Lupan Khola and the Manamati River 


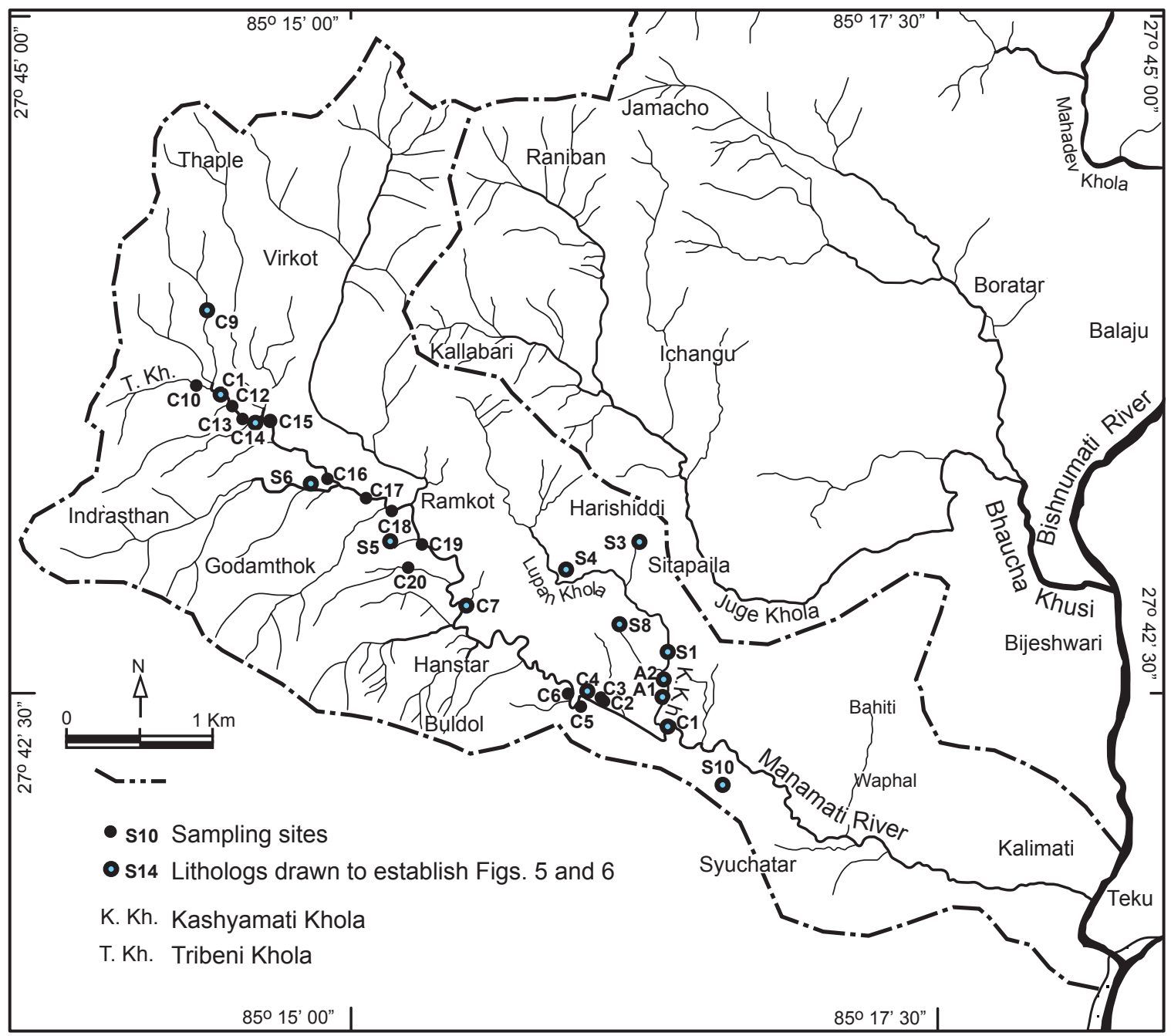

Fig. 5 A map showing location of logging points

transverse fan systems have been developed. The river now incises uplifting terrace deposits, and has a low gradient. It is a sinuous river characteristically carrying mixed loads depending on seasons, and therefore sediment size and amount fluctuates, i. e., episodic bedload transport followed by a long term suspended load transport. Consequently, the riverbeds are produced of muddy gravel substrates. The river also experiences flooding events during which it can carry huge boulders to fines depositing poorly sorted debris, which has been preserved in the upstream portion of the river.

\section{FACIES DESCRIPTION, ANALYSIS AND INTERPRETATION}

The sedimentary records were obtained from different localities (Figs. 5, 6 and 7) and were analysed. Based on lithology, texture, internal sedimentary structure, grain size and boundary condition, eight facies (Table 1) were identified. The facies codes adopted except GF were based on Miall (1999).

\section{Matrix-supported massive gravel Gmm}

$\mathrm{Gmm}$ is matrix-supported, weakly stratified, 
N. K. Tamrakar et al. / Bulletin of the Department of Geology, Vol. 12, 2009, pp. 1-16
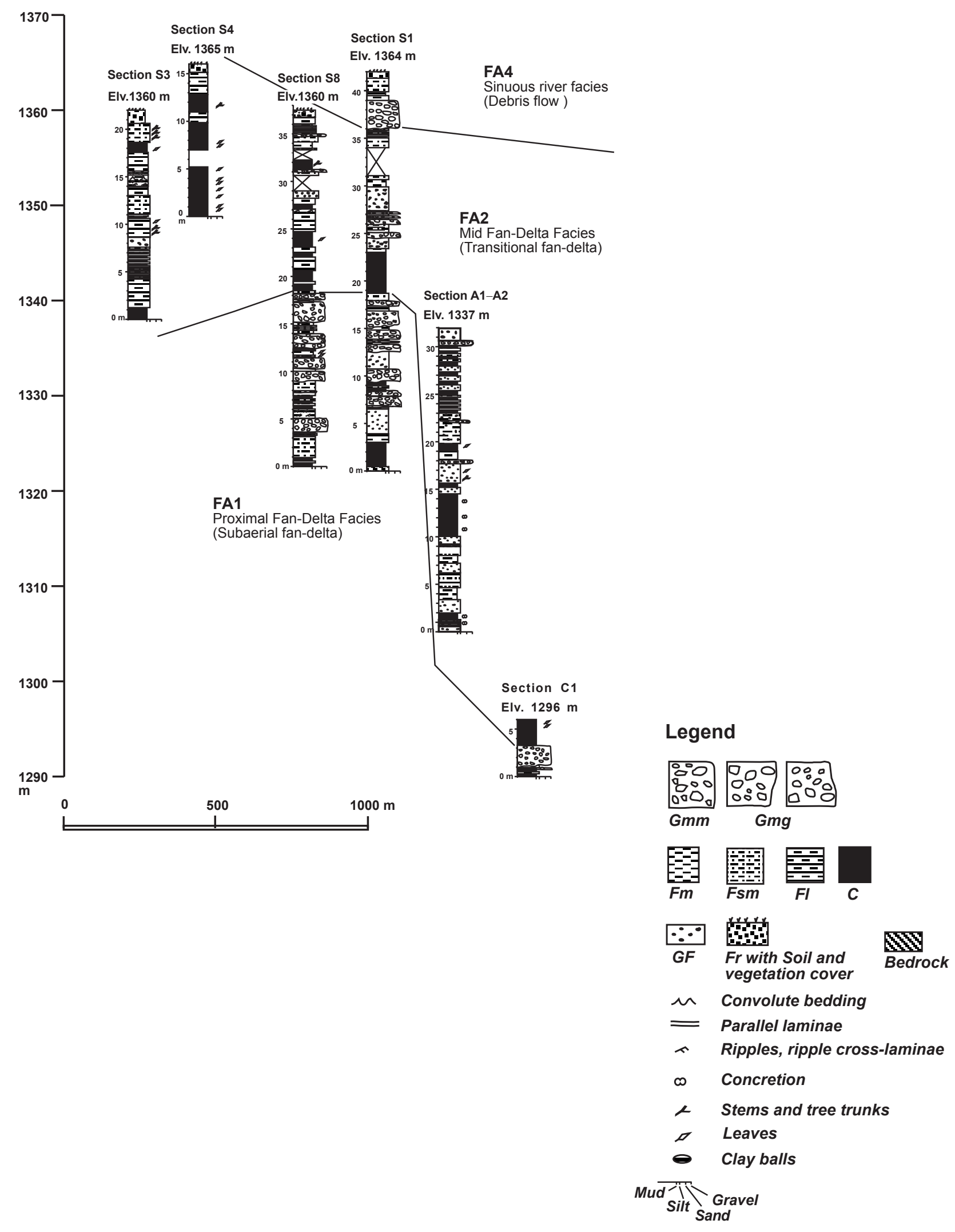

Fig. 6 Distribution of sedimentary sequences at different sections along the Manamati River 


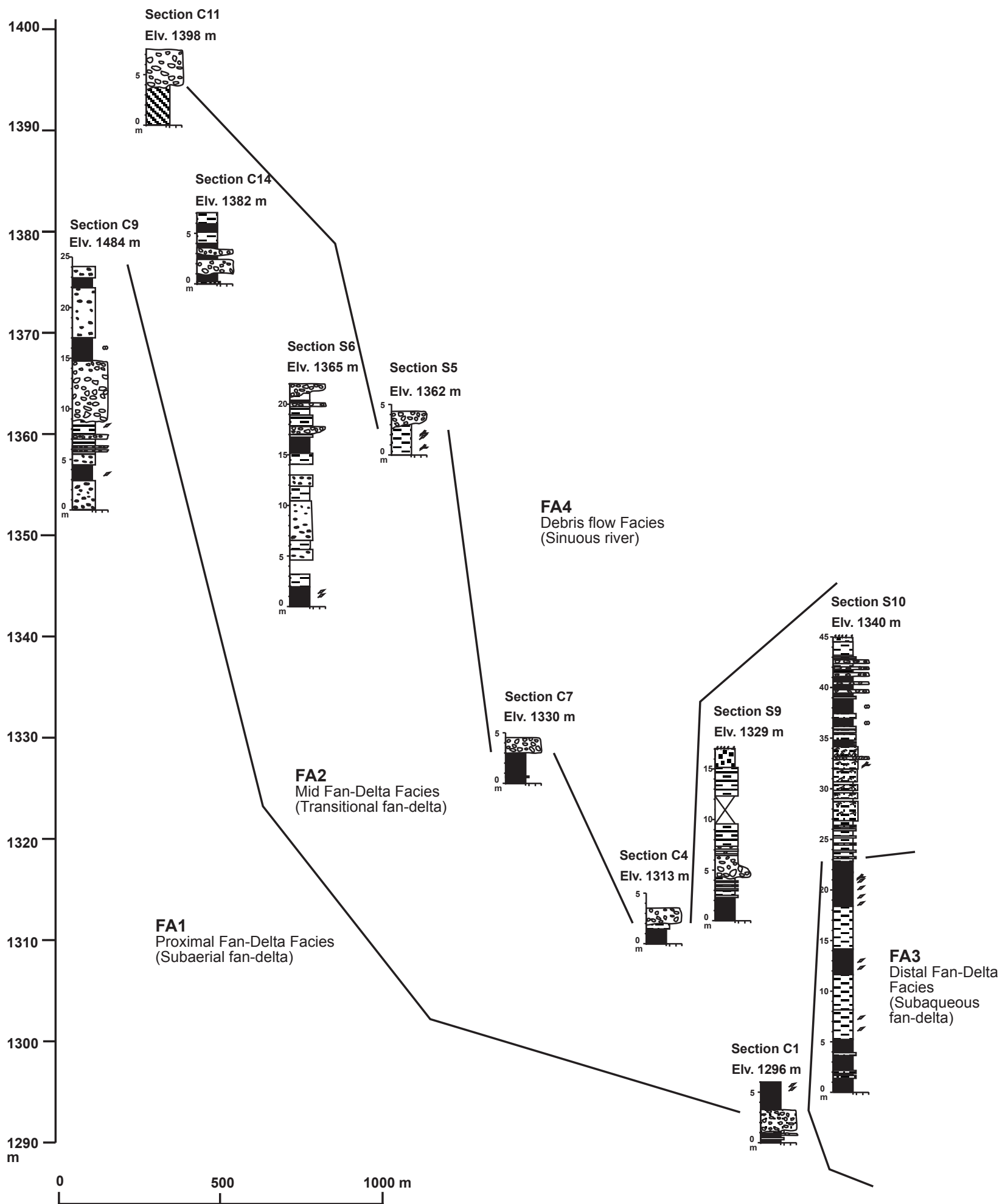

Fig. 7 Distribution of sedimentary sequences along the Lupan Khola (See Fig. 6 for a legend) 
Table 1: Lithofacies definition, description and interpretation (Based on Miall $(1978,1996)$

\begin{tabular}{|c|c|c|c|c|c|}
\hline $\begin{array}{l}\text { Facies } \\
\text { code }\end{array}$ & Definition & Structure & Description & $\begin{array}{l}\text { Major } \\
\text { Transition }\end{array}$ & Interpretation \\
\hline Gmm & $\begin{array}{l}\text { Matrix-supported } \\
\text { massive gravel }\end{array}$ & Massive & $\begin{array}{l}\text { Matrix-supported, weakly stratified, poorly sorted, } \\
\text { undgraded cobble pebble gravel composed of } \\
\text { sandstone, siltstone, shale, phyllite, vein quartz, etc. } \\
\text { clasts showing angular to subangular shape with } \\
\text { disorganised fabric }\end{array}$ & $F l^{*}, C$ & $\begin{array}{l}\text { Viscous and plastic debris } \\
\text { flow deposit }\end{array}$ \\
\hline Gmg & $\begin{array}{l}\text { Matrix-supported } \\
\text { graded gravel }\end{array}$ & $\begin{array}{l}\text { Normal to } \\
\text { reverse } \\
\text { grading }\end{array}$ & $\begin{array}{l}\text { Matrix-supported, weakly stratified, poorly sorted, } \\
\text { poorly graded cobble pebble gravel composed of } \\
\text { siltstone, sandstone, shale, phyllite, vein quartz, etc. } \\
\text { clasts which are subangular to subrounded with } \\
\text { weak imbrication }\end{array}$ & $G F^{*}, F l$ & $\begin{array}{l}\text { Viscous and } \\
\text { pseudoplastic debris flow } \\
\text { deposit }\end{array}$ \\
\hline$G F$ & Gravelly fines & $\begin{array}{l}\text { Massive to } \\
\text { crudely } \\
\text { graded or } \\
\text { laminated }\end{array}$ & $\begin{array}{l}\text { Matrix-supported, poorly sorted, poorly graded } \\
\text { pebbly mud with clasts chiefly composed of } \\
\text { siltstone, sandstone, shale, phyllite, etc., beds rarely } \\
\text { show laminae; (equivalent to diamicton) }\end{array}$ & $\begin{array}{l}\text { Gmg*, } \\
\text { Fm, C }\end{array}$ & $\begin{array}{l}\text { Cohesive debris flow } \\
\text { (Mud flow deposit); } \\
\text { overbank floods }\end{array}$ \\
\hline Fsm & Massive silt/mud & Massive & $\begin{array}{l}\text { Massive to thin bedded, dark grey to brown or } \\
\text { yellowish grey silt and mud with occasional plant } \\
\text { leaves and stems }\end{array}$ & $\begin{array}{l}\mathrm{C}^{*}, \mathrm{Gmm}, \\
\mathrm{Fr}\end{array}$ & $\begin{array}{l}\text { Overbank deposit, back } \\
\text { swamp, suspension } \\
\text { settling, rapid mass } \\
\text { deposition after flooding }\end{array}$ \\
\hline Fm & Massive clay/mud & Massive & $\begin{array}{l}\text { Massive to thin bedded, dark grey to dark brown } \\
\text { clay or mud with organic material }\end{array}$ & $\begin{array}{l}\text { Fsm, } F l, \\
F r\end{array}$ & $\begin{array}{l}\text { Overbank deposit, } \\
\text { abandoned channel } \\
\text { deposit }\end{array}$ \\
\hline$F l$ & $\begin{array}{l}\text { Ripple laminated } \\
\text { silt or planar } \\
\text { laminated silt, } \\
\text { mud or clay }\end{array}$ & $\begin{array}{l}\text { Ripple } \\
\text { laminae, } \\
\text { planar } \\
\text { laminae }\end{array}$ & $\begin{array}{l}\text { Ripple laminated yellow to brown silt, or thick } \\
\text { bedded to thinly laminated grey to yellowish brown } \\
\text { silt or clay or mud }\end{array}$ & $\begin{array}{l}G m m^{*} \\
F r^{*}, F m\end{array}$ & $\begin{array}{l}\text { Sheet flooding and } \\
\text { suspension settiling of } \\
\text { overbank fines }\end{array}$ \\
\hline C & $\begin{array}{l}\text { Dark grey to black } \\
\text { carbonaceous clay }\end{array}$ & $\begin{array}{l}\text { Planer } \\
\text { laminated } \\
\text { to massive }\end{array}$ & $\begin{array}{l}\text { Massive to frequently laminated, dark grey to black } \\
\text { carbonaceous clay with plant leaves, stems, and } \\
\text { occasional vivianite. }\end{array}$ & $\begin{array}{l}F s m^{*} \\
G F, F m\end{array}$ & $\begin{array}{l}\text { Vegetated swamp, } \\
\text { suspension depsition in } \\
\text { reducing environment }\end{array}$ \\
\hline $\mathrm{Fr}$ & $\begin{array}{l}\text { Incipient soil with } \\
\text { roots }\end{array}$ & $\begin{array}{l}\text { Root and } \\
\text { animal } \\
\text { burrows }\end{array}$ & $\begin{array}{l}\text { Grey to yellowish brown top soil with root } \\
\text { penetration or anminal burrowing }\end{array}$ & & $\begin{array}{l}\text { Soil modified by root and } \\
\text { anminal burrows }\end{array}$ \\
\hline
\end{tabular}

* Statistically significant at significance level 0.10

massive, poorly sorted cobble to pebble gravel (Fig. 8a). The gravel clasts are mostly composed of sandstone, siltstone, shale, phyllite, quartz, slate, etc., which are angular to subangular with weak imbrication. Size of the clasts varies slightly within the bed, and varies laterally approaching up to $0.2 \mathrm{~m}$ in the western region (Section S8, Fig. 6). The matrix is composed of mud. The bed thickness ranges from tens of centimeters to more than five metres. Gmm has sharp contacts with other lithofacies, however it possesses erosional relation with underlying beds at many locations.

At section $\mathrm{S} 8, \mathrm{Gmm}$ is very thick-bedded, yellowish grey, silty or muddy matrix-supported cobble pebble and pebble gravel. Clasts are composed chiefly of sandstone, phyllite, shale, quartzite, etc., and are angular to subrounded with poor imbrication fabric. Clast size approaches up to $200 \mathrm{~mm}$. At section $\mathrm{S} 1, \mathrm{Gmm}$ is as in the S8, however, maximum clast size approaches up to $150 \mathrm{~mm}$. Similarly, some moderate to thick beds of Gmm with similar characteristics features are present in sections A1$\mathrm{A} 2$ and $\mathrm{C} 1$.

Along the Manamati River at section C9, Gmm is characterised by thick to very thick bedded, 
(a)
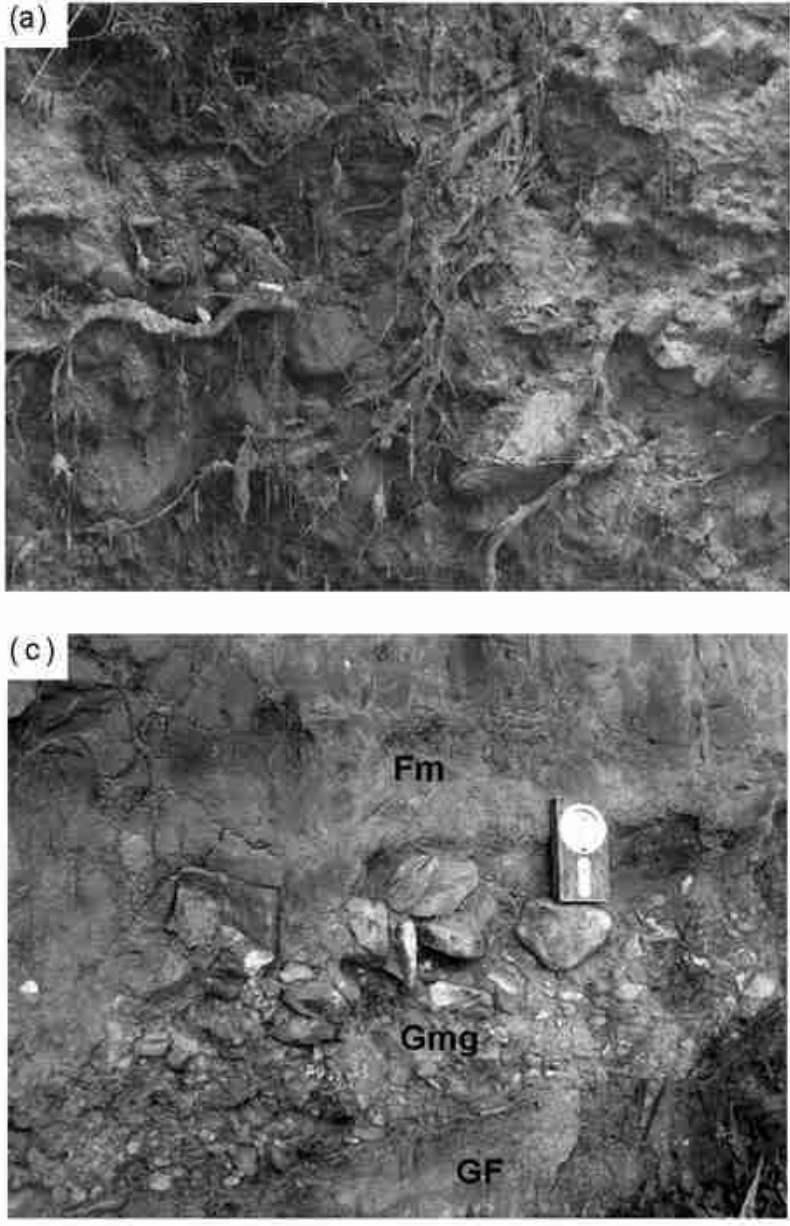

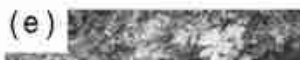

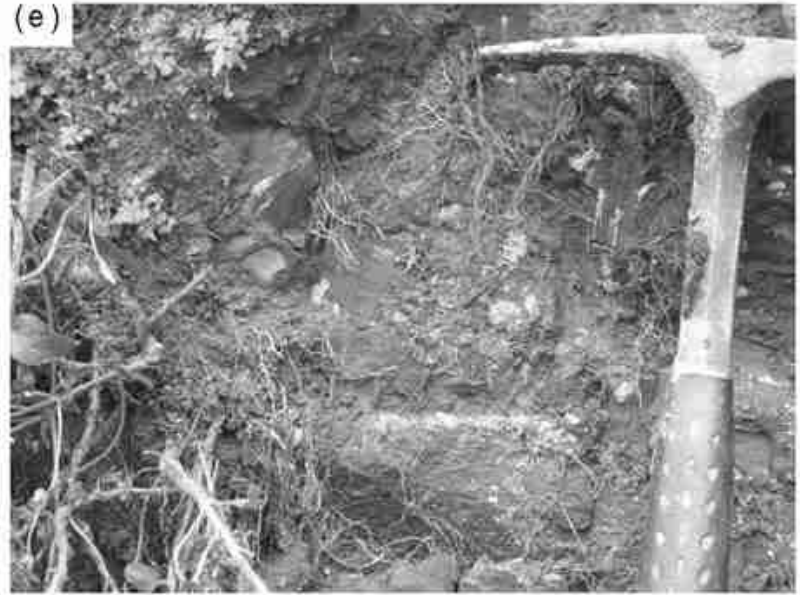

(b)
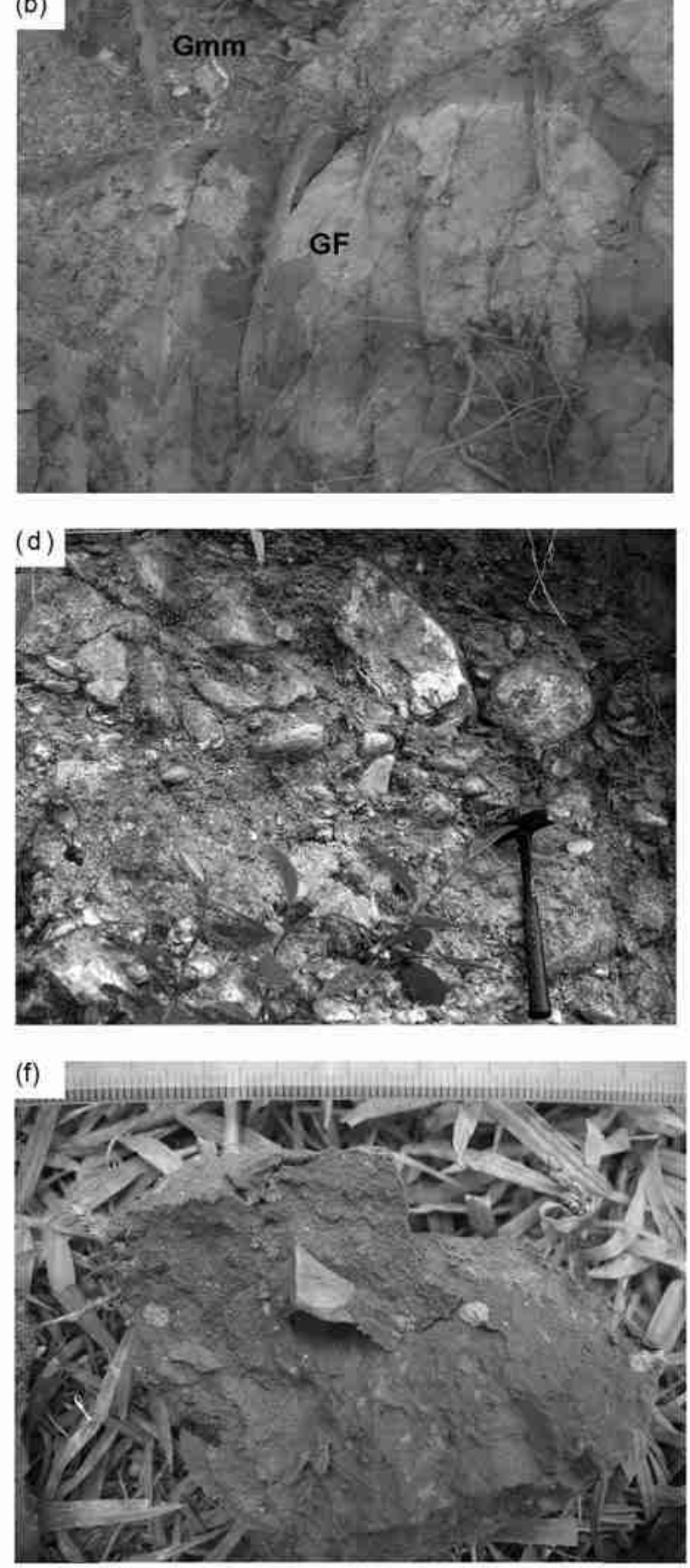

Fig. 8 Photographs showing lithofacies: (a) Gmm as observed at C9, (b) Gmm overlying GF at S1, (c) Gmg at S6, (d) Gmg, matrixsupported reverse graded gravel at S1, (e) GF, gravelly mud at C6, (f) Fragment of the GF in (c) showing angular clasts at closer view. (See Fig. 5 for location) 
brownish grey boulder cobble gravel. Angular to subangular clasts of quartzite, sandstone, phyllite, shale, etc. represent clasts of Gmm. At sections S6 and $\mathrm{S} 9, \mathrm{Gmm}$ is thick bedded, grey to dark brown pebble cobble gravel. Shape and composition of clasts do not change very much. Gmm of section S10 comprises medium bedded, dark grey to brown pebble gravel with angular to subrounded clasts composed of sandstone, phyllite, quartzite, quartz, etc. The gravelly beds are localised at the upper part of the section, and show yellowish brown to dark grey colour. Laterally, grain size and thickness of beds decrease progressively from northwest to southeast region of the study area.

In the measured sections, Gmm shows upward transitions with high difference probability with laminated silt/mud, ripple laminated silt and black carbonaceous clay. GF and Fl is followed by sheetlike Gmm (Fig. 8b). Grain size decreases from NW towards SE sections. The facies represents sub-aerial cohesive debris flow deposit of high viscosity, which was preceded and followed by sheet flood and waning flood stage deposits.

\section{Matrix-supported graded gravel Gmg}

The facies Gmg consists of matrix-supported, weakly stratified, poorly sorted, and often reverse graded (Fig. 8c) to normally graded cobble pebble gravel (Fig. 8d). The clasts are composed mostly of sandstone, siltstone, shale, phyllite, etc. These clasts are angular to sub-rounded and lack proper imbrication. Clast size varies and the maximum size measured is $0.27 \mathrm{~m}$ at section S1. Similarly, thickness of Gmg also varies from tens of centimetres to more than five metres. At section S1, Gmg constitutes very thick bedded, grey to yellowish brown, normally graded, cobble pebble gravel. The clasts are composed of sandstone, shale, siltstone, phyllite, etc., and the maximum size extends up to $270 \mathrm{~mm}$. Gmg at section S6 is reverse graded pebble gravel (Fig. 8c). The clast size here approaches up to $90 \mathrm{~mm}$, and the composition of lithofacies is not so different from that in the section S1. Gmg generally possesses sharp lower contacts with transitional beds, and frequently interbeds with dark grey mud and light grey silt.

Vertically difference probability transitions exist with GF and Fl. Of these upward transitions, one with GF is significant. The facies analysis indicates that the mudflow preceded and followed the cohesive debris flow giving reverse grading. The facies also laterally extends with decreasing grain size towards SE direction.

\section{Gravelly fines GF}

The facies GF comprises thin to thick bedded, poorly sorted, often massive to weakly laminated, dark grey to brown pebbly mud (Figs. 8e and f). The maximum pebble size measured is $0.15 \mathrm{~m}$ in section $\mathrm{S} 1$. The pebbles are composed chiefly of phyllite, siltstone, sandstone, shale, vein quartz etc. Bed thickness varies from tens of centimetres to several metres.

At sections $\mathrm{S} 3$ and $\mathrm{S} 8$, GF is thin to thick bedded, black, grey or yellow brown pebbly mud. Pebbles are poorly sorted, and are composed of sandstone, siltstone, shale, phyllite, etc. At sections S1 and A1A2, GF is very thick to thin bedded, dark brown to grey pebbly mud with tree trunks and plant leaves. Pebble size approaches up to $22 \mathrm{~mm}$ at $\mathrm{S} 1$, and to $100 \mathrm{~mm}$ at A1-A2. At section S6, the lithofacies is very thick bedded, crudely graded, crudely laminated, and dark brown to dark grey pebbly mud.

Vertically, GF facies is well associated with $\mathrm{C}$ and Fm facies. GF is also followed occasionally by Fm. GF indicates cohesive mudflow deposit associated with low viscosity debris flow events. The event such as mudflow followed by channel abandonment and settling of gravel on the earlier swamp (C) is also possible interpretation.

\section{Massive silt/mud Fsm}

The facies Fsm is a massive silt or mud showing dark brown to yellowish grey colour. Fsm occasionally contains plant debris, and its bed thickness ranges from few centimetres to $3 \mathrm{~m}$. Fsm is measured from all the vertical sections with varying thickness and bed repetition. At section S8 it is very thick bedded $(2 \mathrm{~m})$ to thin bedded, and is grey to yellow grey silt. At section $\mathrm{S} 1$, Fsm is very thick bedded $(1 \mathrm{~m})$ to thin bedded and is light grey silt. At section A1-A2, it is medium bedded brown silt, commonly interbedded with carbonaceous clay (C) and matrix-supported massive gravel $(\mathrm{Gmm})$. Vertical transition of probability matrix of Fsm is notable with $\mathrm{C}, \mathrm{Gmm}$ 

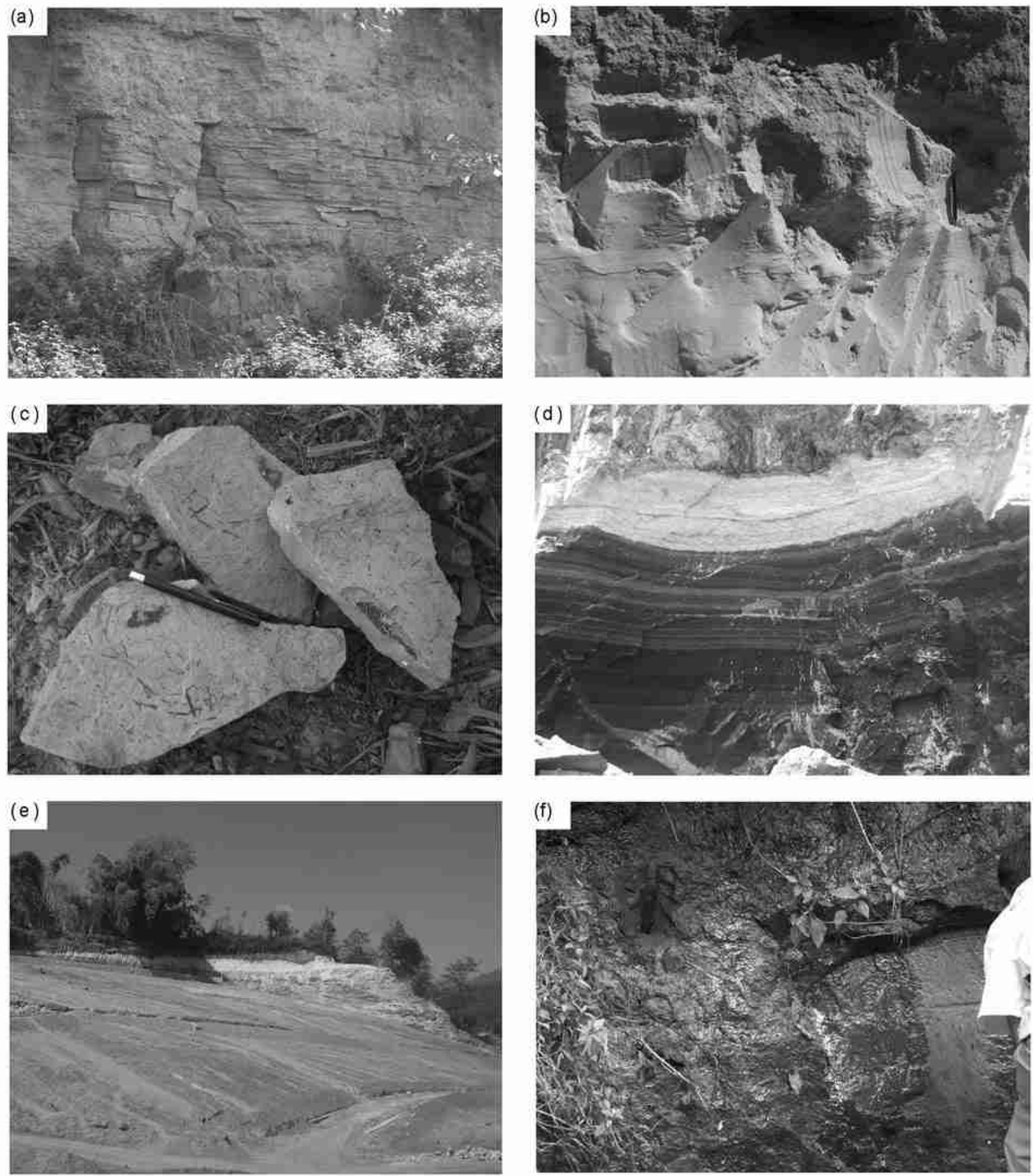

Fig. 9 Photographs showing lithofacies: (a) Laminated silt at A2, (b) Ripple laminated silt at S8, (c) Light grey clay with abundant plant fossils, (d) Laminated dark grey clay overlain by ripple laminated silt and gravelly layer, (e) A vertical sequence at the right bank of the Lupan Khola near the section S1, and (f) Carbonaceous clay at Section A1-A2 
Table 2: Results of facies analysis listing binomial probability for the remarkable transition obtained in difference probability matrix

\begin{tabular}{lccc}
\hline Facies Transition & $\begin{array}{c}\text { Transition } \\
\text { count }\end{array}$ & $\begin{array}{c}\text { Difference } \\
\text { probability }\end{array}$ & Probability \\
\hline $\mathrm{Gmm} \rightarrow \mathrm{Fl}$ & 10 & 0.123 & $0.0598 *$ \\
$\mathrm{Gmm} \rightarrow \mathrm{C}$ & 12 & 0.065 & 0.2624 \\
$\mathrm{Gmg} \rightarrow \mathrm{GF}$ & 4 & 0.446 & $0.0064 *$ \\
$\mathrm{Gmg} \rightarrow \mathrm{Fl}$ & 2 & 0.128 & 0.3087 \\
$\mathrm{Fsm} \rightarrow \mathrm{C}$ & 19 & 0.334 & $0.0002 *$ \\
$\mathrm{Fsm} \rightarrow \mathrm{Gmm}$ & 5 & 0.082 & 0.5718 \\
$\mathrm{GF} \rightarrow \mathrm{C}$ & 12 & 0.083 & 0.1987 \\
$\mathrm{GF} \rightarrow \mathrm{Gmm}$ & 8 & 0.088 & 0.1346 \\
$\mathrm{GF} \rightarrow$ Fm & 5 & 0.022 & 0.4311 \\
$\mathrm{GF} \rightarrow \mathrm{Gmg}$ & 3 & 0.062 & $0.0817 *$ \\
$\mathrm{Fm} \rightarrow$ Fsm & 7 & 0.039 & 0.3295 \\
$\mathrm{Fm} \rightarrow$ Fl & 8 & 0.049 & 0.2606 \\
$\mathrm{Fl} \rightarrow \mathrm{Gmm}$ & 9 & 0.082 & $0.0913 *$ \\
$\mathrm{Fl} \rightarrow$ Fm & 13 & 0.028 & 0.3845 \\
$\mathrm{Fl} \rightarrow$ Fr & 4 & 0.068 & $0.0791 *$ \\
$\mathrm{C} \rightarrow$ Fsm & 22 & 0.110 & $0.0157 *$ \\
$\mathrm{C} \rightarrow$ GF & 14 & 0.028 & 0.1342 \\
$\mathrm{C} \rightarrow$ Fm & 13 & 0.020 & 0.3659 \\
\hline$* \mathrm{Statistically} \mathrm{significant} \mathrm{at} \mathrm{significance} \mathrm{level} \mathrm{of} 0.10$ & \\
& & &
\end{tabular}

and $\mathrm{Fr}$, but the significant one at 0.01 probability is the $\mathrm{C}$ (Table 2). Fsm is associated with overbank deposit, back swamp, suspension settling and rapid mass deposition after flooding.

\section{Massive clay/mud Fm}

The facies Fm consists of massive to thick bedded, dark grey to dark brown clay or mud. Leaf and wood fragments are frequently present in this facies. Bed thickness varies from few centimetres to several metres.

At sections $\mathrm{S} 8, \mathrm{~S} 1$ and $\mathrm{A} 1-\mathrm{A} 2, \mathrm{Fm}$ is thin to thick bedded, grey or yellowish brown to reddish brown massive mud. At section S6, the Fm is characterised by dark grey clay (Fig. 8c) or dark brown mud with thickness ranging from 1 to 2.5 metres. It is light grey silt or brown grey clay with thickness varying from 1 to $1.5 \mathrm{~m}$ at section $\mathrm{S} 9$. The facies Fm, which is characteristic at the lower part of the section, is represented by very thick bedded (4 to $6 \mathrm{~m}$ ), light grey clay with abundant plant leaves and organic fragments.

The difference probability transitions indicate that upward transition of $\mathrm{Fm}$ into $\mathrm{Fsm}, \mathrm{Fl}$ and $\mathrm{Fr}$, and that from GF, $\mathrm{C}$ and $\mathrm{Fl}$ into $\mathrm{Fm}$ are significant. Fm is considered as the overbank fine or abandoned channel deposit. The event that followed mudflows, sheet floods and back swamp gave rise to Fm. It preceded sheet flooding, back swamp and overbank development. Thickness and frequency of Fm increase from NW to SE region in the measured sections (Figs. 6 and 7).

\section{Ripple laminated silt or laminated silt/mud/clay Fl}

The Fl facies comprises laminated or ripple laminated silt, and laminated mud or clay (Figs. 9a and b). They are grey to yellow or brown. Often they are laminated silty clay or silty mud with plant fragments. In the lower part of the sequence of S10, laminated light grey clay with abundant plant fragments (Fig. 9c) can be observed. The thickness of $\mathrm{Fl}$ beds ranges from few centimetres to several metres (often upto $5 \mathrm{~m}$ ).

At sections $\mathrm{S} 3, \mathrm{~S} 4$ and $\mathrm{S} 8, \mathrm{Fl}$ facies is thin to very thick bedded, ripple laminated or laminated sometimes with convolution, and are yellowish grey, grey, dark grey, yellowish brown or brown silt and less commonly mud or clay. At S1, A1-A2, C9, S6 and S9 the facies is medium to very thick bedded, laminated light to dark grey, yellowish grey or brown silt and mud. At section S10, F1 is thin to very thick bedded, ripple laminated and light to dark grey silt.

$\mathrm{Fl}$ is frequently associated with $\mathrm{Gmm}, \mathrm{Fm}$ and Gmg. The probability transitions from Fl to Gmm and from $\mathrm{Gmm}$ to $\mathrm{Fl}$ both are significant indicating their close association. The Fl facies was deposited by sheet floods or waning flood stage. The viscous debris flow preceded and followed the events of Fl deposition.

\section{Carbonaceous clay $\mathbf{C}$}

Massive to mostly laminated black or dark grey carbonaceous clay or organic rich clay (Figs. 9d and $9 \mathrm{e})$ is designated the facies $\mathrm{C}$. This facies frequently contains plant leaves and stems. It occasionally contains vivianite nodules. Bed thickness ranges from few centimetres to few metres. Laterally beds are sheet-like. The lithofacies $\mathrm{C}$ is frequently massive or very thick bedded (Fig. 9f) and sometimes laminated in the southeastern part (sections S3, S4, S1, S8, A1$\mathrm{A} 2$, and $\mathrm{S} 10$ ). 
Bed thickness, laminae, colour and composition of the facies indicate its formation at vegetated swamps or pond environment having calm and reducing conditions, and perhaps in humid climate. The facies $\mathrm{C}$ has significant transition probability to Fsm and from Fsm (Table 2). Besides, areas with some mudflow deposits (GF) and viscous debris flow deposits (Gmm) also changed to swamps, and the latter were occasionally flooded by mudflows.

\section{Incipient soil with root $\mathrm{Fr}$}

The uppermost part of the sedimentary sequence developed has grey to yellowish brown silt or mud with roots and burrows. This soil layer is designated as Fr produced by weathering. The Fr facies occupies mostly the top of the sequence and the transition from $\mathrm{Fl}$ to $\mathrm{Fr}$ is significant.

\section{FACIES ASSOCIATION AND DEPOSITIONAL ENVIRONMENT}

Four facies associations have been identified; proximal fan-delta, mid fan-delta, distal fan-delta, and recent meandering river. The proximal and mid fan-deltas constitute subaerial portion of the system and distal fan-delta is a subaqueous system. The meandering river system is an ongoing fluvial system in the basin. Its deposits have been distributed on most of the terrace surfaces as the river system sculptured these surfaces by gradual shifting and incising the valley into the present channel and landscape therein.

\section{Proximal fan-delta facies association FA1}

Facies association of proximal fan-delta (FA1) comprises major facies Gmm, Gmg and GF while subordinate facies $\mathrm{Fl}$ and $\mathrm{C}$ (Table 3, Fig. 10a). The thickness of $\mathrm{Gmm}$ varies from o. 6 to $2 \mathrm{~m}$ and is thicker in sections located northwestward. Gmg ranges from 1.0 to $2 \mathrm{~m}$ in thickness and occurs occasionally. GF varies in thickness from few centimetres to meters (nearly $4 \mathrm{~m}$ ). $\mathrm{Fl}$ and $\mathrm{C}$ are minor facies but are found frequently associated with $\mathrm{Gmm}$ and Gmg. FA1 contains dominantly the viscous debris flow deposits and mudflow facies with minor sheet flooding facies. The facies association FA1 is the product of deposition from sediment gravity flows on subaerial fan-delta, most possibly on the proximal part of the fan-delta.

On the proximal fan-delta in this case has been affected by the wandering river gravels that were fed by the alluvial system further upstream. The system covers subareal delta and fan fringe. Absence of preferred orientation of clasts, organization of clasts, poor modification of shape, poor sorting and matrixsupported fabric of dominant lithofacies $\mathrm{Gmm}$ and Gmg suggests that wandering river gravel perhaps deposited with frequent sediment gravity flows. Development of small ponds and swamp on flood basin and occasional flooding are indicated by $\mathrm{C}$ and Fl facies.

\section{Mid fan-delta facies association FA2}

Facies association of mid fan-delta comprises Fl, $\mathrm{C}, \mathrm{Fm}$ and GF as major facies, and Gmm and Fsm as subordinate facies (Fig. 10b). The thickness of Fl ranges from few centimetres to $2 \mathrm{~m}$, and that of $\mathrm{C}$ from few $\mathrm{cm}$ to $5 \mathrm{~m}$. Gmm and Fsm occur occasionally and as thin layers. FA2 indicates deposition in mid fan-delta, which was transitional

Table 3: Facies association, depositional process and environment

\begin{tabular}{|c|c|c|c|c|}
\hline $\begin{array}{l}\text { Facies } \\
\text { Assemblage }\end{array}$ & Main Facies & Minor Facies & Depositional process & Depositional Environment \\
\hline FA1 & Gmm, Gmg, GF & Fsm, $\mathrm{Fl}, \mathrm{C}$ & Debrisflow, mudflow, sheet flooding & Proximal fan-delta \\
\hline FA2 & $F l, C, F m, G F$ & Gmm, Fsm & $\begin{array}{l}\text { Sheet flooding, channel abandonment, } \\
\text { swamp development }\end{array}$ & Mid fan-delta \\
\hline FA3 & $C, F m$ & Fsm & $\begin{array}{l}\text { Vertical accretion of fines, minor } \\
\text { stream flow }\end{array}$ & Distal fan-delta \\
\hline FA4 & Gmm, Fsm & $F l, F m$ & Debris flow, overbank flood & Sinuos river \\
\hline
\end{tabular}




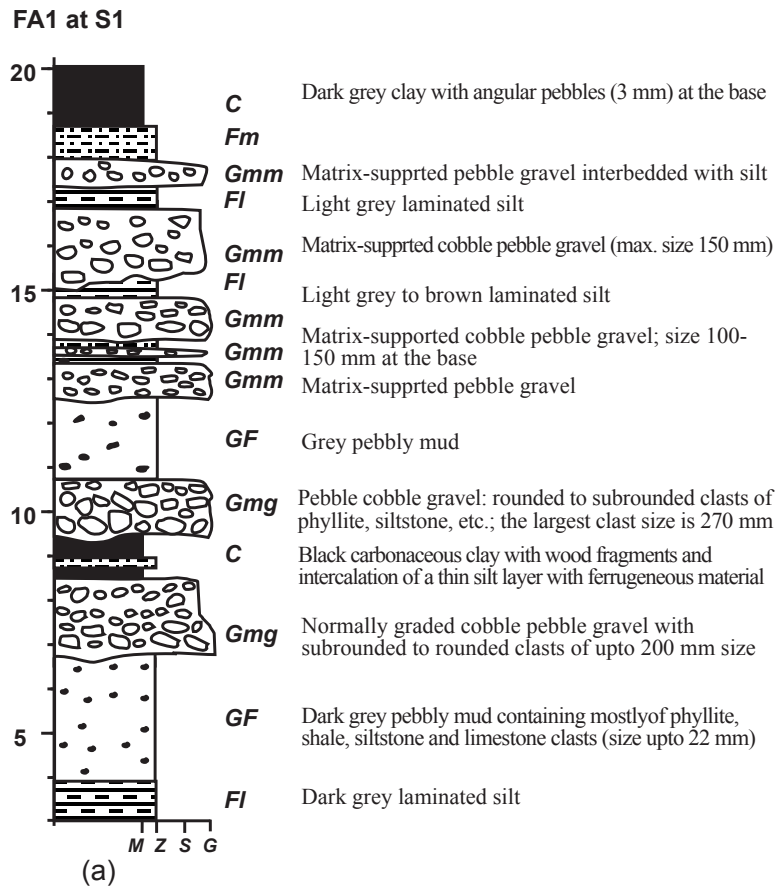

FA3 at $\mathrm{S} 10$

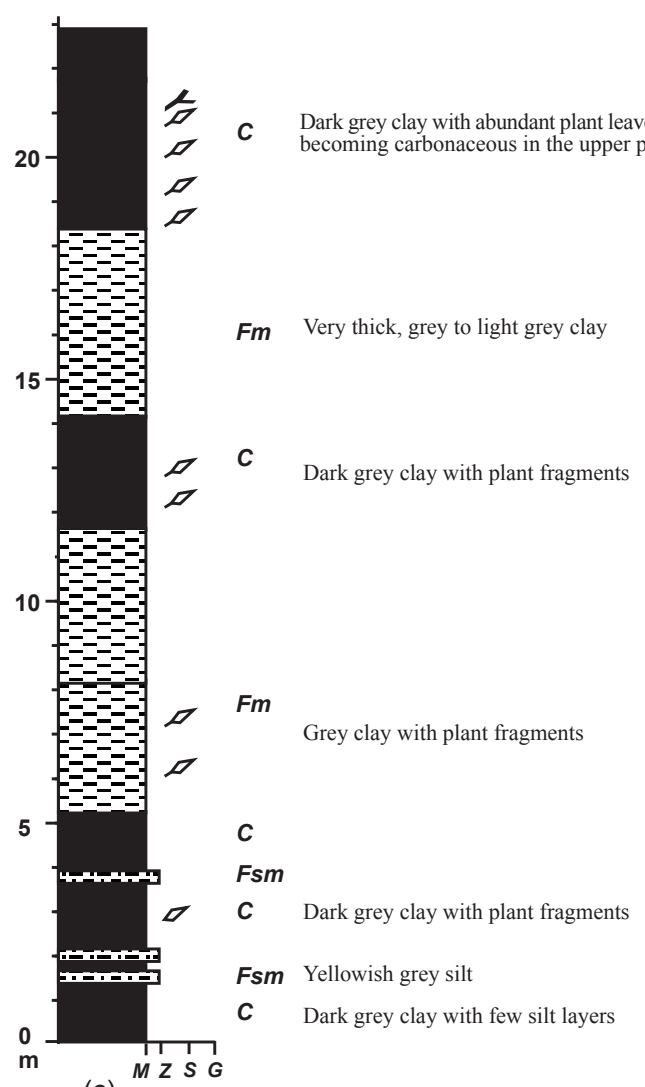

(c)

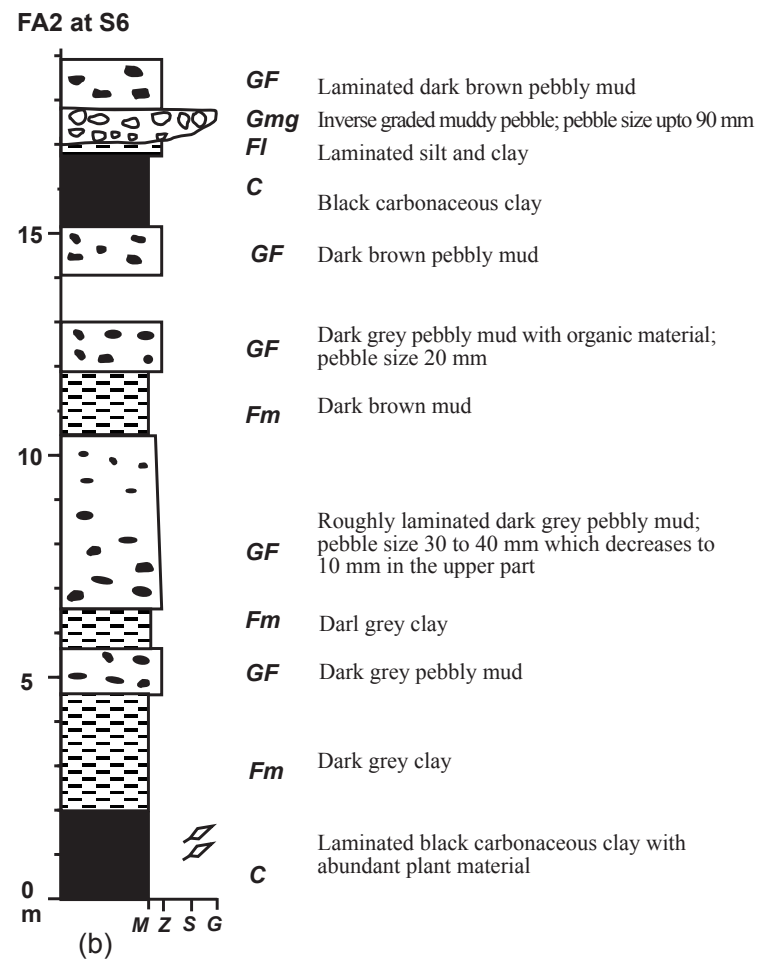

(b)

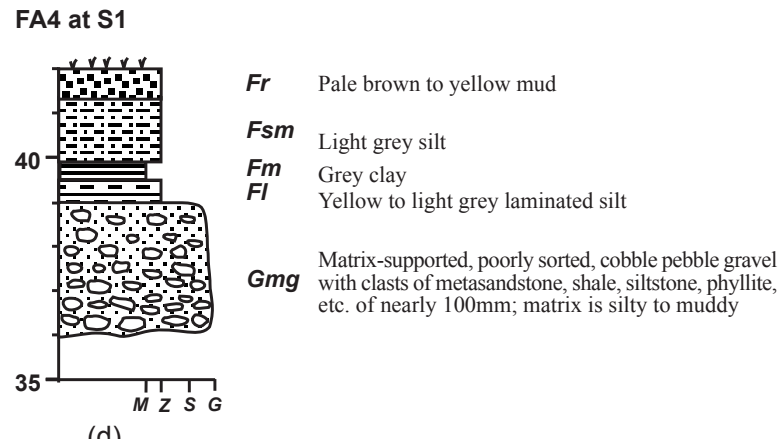

Fig. 10 Facies associations (a) Proximal fan-delta facies association (subaerial fan-plain), (b) Mid fan-delta facies association (transitional fan-delta), (c) Distal fan-delta facies association (subaqueous fan-delta), and (d) Sinuous river facies assemblage 
to the proximal fan-delta and the distal fan-delta, and was affected by lake-level fluctuations.

FA2 was produced by frequent sheet flooding or unconfined flooding of silt, and of mudflow leaving the channel and over-topping the banks. The river channels (distributaries) in this low-gradient plain could have low strength to carry coarse debris except during the flooding period. The flooding events associated frequently with development of vegetated swamps. Occasional viscous debris flows and channel abandonment also took place. The event was followed by development of swamps or ponds. Fluctuation of lake-level could have helped in keeping the flood basins as wetlands.

\section{Distal fan-delta facies association FA3}

The facies association of distal fan-delta consists of major facies $\mathrm{C}$ and $\mathrm{Fm}$, and minor facies Fsm (Fig. 10c). The thickness of $\mathrm{C}$ and $\mathrm{Fm}$ may individually exceed $4 \mathrm{~m}$. FA3 is dominated by organic rich carbonaceous clay and mud little affected by minor stream flows. The facies association indicates that the sediments were deposited in a calm environment where vertical suspension fall out was dominant. Green grey, dark grey or black facies with organic debris indicate reducing depositional environment. The distal fan-delta facies association extends southeastwards (paleo-lake) with more well developed thick-sequence of carbonaceous and muddy sediment of the Kalimati Formation (Sakai 2003) which is open lacustrine facies (Paudel and Sakai 2008).

\section{Gravelly sinuous river facies association FA4}

The gravelly sinuous river of recent environment has deposited mainly Gmm and Fsm facies and minorly Fl and Fm facies (Fig. 10d). The major facies were deposited by viscous debris flow intermittent with overbank flooding and vertical settling of fines. Frequently, Gmm facies overlie bedrocks and mid fan-delta facies.

\section{DISCUSSIONS}

Distribution of lithofacies in vertical sequence, lateral extent and association of lithofacies characterise the basin fill sediment. Eight lithofacies, which have been defined, contain no sandy facies. The facies associations indicate that the basin margin in southwest region of Kathmandu was fan-delta environment in which alluvial fan directly met with a lake and was a narrow margin with proximal fan-delta, mid fandelta and distal fan-delta (subaqueous). The facies associations of older sediments as well as bedorcks are unconformably overlain by debris flow deposits of subsequent events. Absence of sandy beds and of foresets is quiet remarkable feature of the sequence developed in the southwest region of the Kathmandu basin. Lack of sandy facies can be attributed to (a) source rock type failing to produce sand-sized grains (e.g., siltstone, fine sandstone, shale, limestone, phyllite and slate give rise to either gravel or mud), and to (b) river flow dynamics.

On the other hand, the river that brought debris from fans should have small watershed and low gradient, and had behaved passively unless was supplied with huge debris during rainstorm. Such river carried massive debris during rainstorm, and carried suspended fines after the subsidence of flood. The traction transport was almost rare. Presence of matrix-support fabric in sheet-like gravel (Gmm and Gmg), lack of proper imbrication, poor sorting, angularity of clasts, and absence of clast-supported fabric and cross stratification support this nature of flow. Soft and fine-grained nature of source area rocks perhaps yielded either coarse or fine detritus. Sediments derived to the fan-delta depended on both source rock type and river dynamics, and this suggests debris flow followed by waning stage of flood events, and therefore the river then should be of flood-flow dominated wandering river.

On the proximal portion of fan-delta, the river could be prominent distributary but further downstream the distributaries could have gradually vanished into impounded water body, without huge load. Because of low supply of sediment and lack of uniform mixing, the delta failed to develop Gilberttype foresets. The other reasons being the nature of sediments shed, extensive development of vegetated swamps and flood basin, and transgression of lake.

Distribution of lithofacies associations exhibits the proximal fan-delta sequence at the lower part of the basin-fill sediments. It is overlain by mid fandelta facies due to transgression of lake. The major 
portion of the proximal fan-delta facies was overlain by the mid fan-delta facies and was inturn overlain by the distal fan-delta facies, while proximal fandelta facies were depositing more landward to higher elevation. This indicates transgression of lake. It was followed by the rapid regression of lake during which earlier deposited sediments were probably eroded away or reworked towards the lake, which was possibly related to outlet of lake water from the Kathmandu basin (Sakai 2001). With reduction in lake level, base level of the main rivers diminished, and sculpturing of terrace landform by the flooddominated sinuous river against uplifting landmass had occurred. These rivers also deposited debris flow sediments. More recently, the Manamati River and the Lupan Khola have been incising the river terrace of the fan-delta sequence. The Manamati River finally carries debris to the Bishnumati River.

\section{CONCLUSIONS}

1. The basin fill sediments of southwest Kathmandu Basin in Manamati River area are distinguished into eight lithofacies. These facies are massive matrix-supported gravel, massive matrixsupported graded gravel, gravelly fines, massive silt, massive $\mathrm{mud} / \mathrm{clay}$, laminated mud/clay/silt or ripplelaminated silt, carbonaceous clay, and incipient soil with root. Lack of sandy facies is attributed to both provenance and depositional environment.

2. Four facies associations identified are proximal fan-delta, mid fan-delta, distal fan-delta and recent sinuous river. Wandering flood-flow dominated distributaries with vegetated swamps and flood basins, and the recent sinuous river have been recorded in the sedimentary sequence. The lithofacies in both cases were influenced by source rock composition and river dynamics.

3. Distribution of facies associations records transgression of lake followed by rapid regression, and upliftment of landforms and river incision, which were related to local upliftment caused by faulting or base level lowering of the main river in the Kathmandu Basin as a consequence of draining out of the lake water.

\section{REFERENCES}

Billi, P., Magi, M., and Sagri, M., 1991. Pleistocene lacustrine fan delta deposits of the Valbarno basin, Italy. Jour. Sed. Petrology, v. 61, no. 2, pp. 280-190.

DMG, 1998. Engineering and environmental geological map of the Kathmandu Valley, scale 1:50000. Department of Mines and Geology (DMG) in cooperation with Bundesanstait fur Geowissenschaften und Rostoffe, DMG, Lainchaur, Kathmandu, Nepal.

McPherson, J.G., Shanmugam, G., Moiola R.J., 1987. Fan deltas and braid deltas: Varieties of coarse-grained deltas. Geol. Soc. Ame. Bull., v. 99, pp. 331-340.

Miall, A.D., 1996. The geology of fluvial deposit. SpringerVerlag, 582p.

Miall, A.D., 1978. Lithofacies types and vertical profile models in braided river deposits; a summary. In: Miall A.D. (ed) Fluvial Sediementology. Can. Soc. Petrol. Geol. Mem. Soc.: pp. 597-604.

Paudel, M. R. and Sakai, H., 2008. Stratigraphy and depositional environments of basin-fill sediments in southern Kathmandu Valley, Central Nepal. Bull. Dept. Geology, T.U., v. 11, pp. 61-70. doi: 10.3126/bdg.v11i0.1544

Saijo, K. and Kimura, K, 2007. Expansion of an ancient lake in the Kathmandu basin of Nepal during the Late Pleistocene evidence by lacustrine sediment underlying piedmont slope. Himalayan Journal of Sciences, v. 4, no. 6 , pp. 41-48.

Sakai, H., 2001. Stratigraphic division and sedimentary facies of the Kathmandu Basin Group, central Nepal. Jour. Nepal Geol. Soc., v. 25, pp. 19-32.

Sakai, H., Fujii, R., Kuwahara, Y., Upreti, B.N. and Shrestha, S.D., 2001. Core drilling of the basin-fill sediments in the Kathmandu Valley for palaeoclimatic study: preliminary results. Jour. Nepal Geol. Soc., v. 25, pp. 9-18.

Sakai, T., Gajurel, A.P., Tabata, H., and Upreti, B.N., 2001. Small-amplitude lake-level fluctuations recorded in aggrading deltaic deposits of the Upper Pleistocene Thimi and Gokarna formations, Kathmandu Valley, Nepal. Jour. Nepal Geol. Soc., v. 25, pp. 43-52. 